\title{
PEMBELAJARAN SEJARAH LOKAL BERBASIS RE- ENACTMENT DALAM KOMUNITAS PENGGIAT SEJARAH ROODEBRUG SOERABAIA
}

\author{
Rintahani Johan Pradana \\ Pascasarjana Pendidikan Sejarah, Universitas Negeri Malang
}

\begin{abstract}
Abstrak: Pendirian komunitas penggiat sejarah sebagai respon pada potensi sejarah lokal. Re-enactment menjadi salah satu cara komunitas ini dalam memperkenalkan sejarah lokal pada masyarakat. Penelitian ini berupaya menggambarkan kembali peristiwa sejarah oleh komunitas roodeburg Soerabaia. Penelitian ini menggunakan metode kualitatif deskriptif. Hasil penelitian ini menunjukkan bahwa Surabaya memiliki potensi sejarah lokal yang sangat bagus dengan dukungan perlindungan terhadap situs sejarah dan bangunan cagar budaya melalui peraturan perundang-undangan. Hal ini juga disambut dengan respon masyarakat, melalui komunitas penggiat sejarah dan salah satunya adalah Roodebrug Soerabaia.
\end{abstract}

Kata-kata kunci : sejarah lokal, Surabaya, Roodebrug Soerabaia, Re-enactment

\begin{abstract}
The establishment of historical activist-community as a response to local history potential. Re-enacment becomes a way in introducing local history to society. This study tends to re-enact the historical events by the Roodeburg Soerabaia. This study used descriptive-qualitative method. The results showed that Surabaya has the potential of local history which was very nice with the support of the protection of historical sites and heritage buildings through legislation. It also welcomed the response of the community, through historical activistcommunity and one of them is Roodebrug Soerabaia.
\end{abstract}

Keywords: local history, Surabaya, Roodebrug Soerabaia, Re-enactment

Surabaya memainkan peranan penting dalam lintas sejarah Indonesia. Peranan ini dibuktikan dengan keberadaan karya historiografi yang mengupas sejarah lokal Surabaya dan peninggalan-peninggalan sejarah yang ada. Sumber tertua yang menyebut nama Surabaya adalah prasasti Trowulan I dengan angka tahun 1280 çaka atau 1358 masehi. Prasasti ini mencantumkan sederet nama dermaga transportasi sungai yang berada di sepanjang aliran Sungai Brantas (Timoer, 1983: 13). Sumber tersebut masih menjadi perdebatan mengenai asal-usul nama Surabaya.

Keterkaitan Surabaya dengan aktivitas pelayaran dan perdagangan juga berdampak pada peran penting kota ini sebagai bandar dagang, sekaligus pintu masuknya beragam kebudayaan. Ricklefs (1989:3) berpendapat bahwa pedagangpedagang muslim yang berasal dari Arab, Persia, dan India singgah di kepulauan Indonesia dalam rangka berdagang serta menyebarkan ajaran agama Islam. Aktivitas ini diperkirakan telah terjadi sejak abad ke tujuh dan perlahan pedagangpedagang tersebut bermukim serta membentuk kelompok di kota-kota pelabuhan di Pulau Jawa.

Pondasi budaya tampak telah kuat dibangun oleh kelompok-kelompok sosial muslim di wilayah pesisir, termasuk Surabaya. Hal itu menyebabkan Islam dapat berkembang pesat di Surabaya dengan mudah. Pada kisaran tahun 1450 telah didirikan tempat peribadatan kaum muslim di Surabaya yang digerakkan oleh 
Sunan Ampel (Wiryoprawiro, 1986: 182). Keberadaan sarana pendukung ini, tentu membuat Surabaya menjadi salah satu kota pesisir dengan tingkat perkembangan yang cukup pesat.

Pada masa pendudukan Daendels (1808-1811), Surabaya kembali mengalami perkembangan lebih lanjut. Daendels membangun berbagai sarana untuk mendukung tujuan utamanya dalam mempertahankan Jawa dari pengaruh dan ancaman Inggris. Pada masa pendudukannya, Daendels membangun sebuah benteng dan gudang perbekalan logistik maupun amunisi tempur di Surabaya (Thorn, 2011: 280 \& 282). Pembangunan hingga perbaikan fungsi ini turut mempengaruhi dinamika perkembangan Surabaya menjadi salah satu kota yang cukup memiliki peran besar di Jawa Timur. Dapat disimpulkan bahwa pada awal abad ke 19 inilah, sarana dan prasarana yang ada semakin mendukung peran Surabaya sebagai bandar dagang dan pelabuhan modern.

Ditinjau dari segi secara adminitratif, perkembangan Surabaya dimulai pada awal abad ke 20. Pada 1906 Surabaya ditetapkan sebagai gemeente (Basundoro 2013: 30). Penetapan sebagai gemeente semakin mempertegas posisi penting serta menjadi dampak lebih lanjut dari perkembangan wilayah Surabaya yang telah memenuhi persyaratan untuk menjadi wilayah administratif kota praja. Pengaruh lebih lanjut tentu terjadi pada ranah pembangunan sarana dan prasarana kota yang menyesuaikan dengan kondisi zaman. Pada masa inilah Surabaya telah dapat dikatakan sebagai suatu kota yang mulai memiliki perangkat penggerak aktivitas yang lebih legal, yang diatur melalui peraturan pemerintah kota praja.

Jepang memulai lembaran baru pada sejarah bangsa Indonesia melalui usaha pendudukan pada bulan Februari hingga
Maret 1942. Penegakkan peraturan bidang politik dan ekonomi menjadi salah satu gagasan utama yang dilaksanakan oleh Jepang di wilayah Asia Timur. Indonesia menjadi salah satu negara yang mendapat perhatian karena keberadaan beragam sumber daya alam yang dibutuhkan oleh Jepang (Notosusanto, 1979: 29-30). Praktik selanjutnya justru memberikan kerugian besar terhadap pihak Indonesia melalui berbagai kebijakan, seperti kerja paksa hingga pengambilan sumber daya alam dalam skala cukup besar. Kerja paksa yang dilakukan oleh Jepang, yang lazim dikenal dengan istilah, berdampak pada timbulnya keresahan yang cukup serius pada kalangan Arek-arek Suroboyo (Frederick, 1989:135). Kekecewaan ini kemudian menjadi suatu akumulasi kekecewaan dari Arek-arek Suroboyo pada pemerintah Jepang. Dampak dari kekecewaan Arek-arek Suroboyo sewaktu Jepang menyerah kalah pada sekutu, mulai timbul aksi-aksi pemberontakan terhapan kekuasaan Jepang di Surabaya, pasca proklamasi kemerdekaan Republik Indonesia. Aksi ini diwujudkan melalui konsolidasi kekuatan untuk melucuti senjata milik pasukan Jepang dan menolak kembalinya beragam praktik imperialis di Surabaya (Abdulgani, 1980: 6). Kejadian demi kejadian yang terjadi pasca proklamasi kemerdekaan Republik Indonesia di Surabaya, dalam kurun waktu September hingga Oktober 1945, turut mengiringi timbulnya pertempuran yang lebih besar pada minggu ke dua bulan November 1945 hingga awal Desember 1945.

Pertempuran Surabaya yang terjadi pada tanggal 10 Nopember 1945, menjadi salah satu wujud perjuangan mempertahankan kemerdekaan oleh bangsa Indonesia yang paling dikenang dan memberikan banyak pengaruh. Pertempuran ini melibatkan warga Surabaya, yang lebih sering disebut dengan 
arek-arek Suroboyo, bersama dengan kekuatan dari berbagai wilayah di Indonesia. Lawan utama dalam perjuangan mempertahankan kemerdekaan ini ialah tentara Inggris yang baru saja memenangkan perang dunia ke dua. Pertempuran Surabaya menghabiskan waktu hampir satu bulan penuh dan memakan banyak korban di antara ke dua belah pihak. Doulton (2002: 267), salah satu Kolonel Inggris dalam pertempuran Surabaya, menuliskan bahwa pertempuran Surabaya tidak ubahnya seperti 'neraka' bagi tentara Inggris di timur Jawa. Doulton mengenang, sekitar 220 anggotanya terbunuh dan jumlah ini belum termasuk keseluruhan jumlah dari tentara Inggris dalam pertempuran Surabaya 1945.

Mengenang pertempuran ini dengan peringatan hari pahlawan setiap tanggal 10 Nopember merupakan salah satu cara yang dilakukan untuk menghormati pengorbanan terbesar yang pernah diberikan oleh arek-arek Suroboyo dalam mempertahankan kemerdekaan Indonesia. Pertempuran ini meninggalkan kisah heroic atas perlawanan bangsa Indonesia dan usahanya dalam mempertahankan kemerdekaan. Tidak berlebihan apabila kemudian peristiwa tersebut dikenang dan menghadirkan semangat patriotis pada diri arek-arek Suroboyo. Pada beberapa sudut kota Surabaya, dengan mudah dijumpai keberadaan monument-monumen sebagai penjaga memori atas peristiwa pertempuran 10 Nopember 1945 dan menjadi sebuah penanda yang coba menegaskan posisi Surabaya sebagai kota Pahlawan.

Berbagai peristiwa sejarah yang terjadi di Surabaya telah meninggalkan jejak. Beberapa di antaranya berupa bangunan, benda-benda peninggalan sejarah, hingga monument sebagai suatu penanda sekaligus penjaga memori terhadap sebuah peristiwa. Peninggalanpeninggalan sejarah ini tersebar di beberapa titik di kota Surabaya sekaligus mempertegas identitas Surabaya sebagai kota Pahlawan dan kota yang memiliki nilai sejarah. Berdasar pengamatan yang dilakukan oleh peneliti di kota Surabaya, peninggalan sejarah maupun monumen yang ada lebih merepresentasikan Surabaya sebagai kota perjuangan. Hal ini dibuktikan dengan banyaknya monumen-monumen perju-angan yang ada, dan bangunanbangunan peninggalan masa kolonial Belanda dengan gaya arsitekturnya yang khas. Keberadaan bangunan tersebut terdapat di wilayah Kota Surabaya bagian utara, sebagai kota kuno Surabaya, dan wilayah sekitaran Jalan Tunjungan.

Pemerintah kota Surabaya turut memberikan respon melalui UU no 5/1992 tentang pelestarian cagar budaya, melalui Perda no. 5 tahun 2005. Peraturan daerah ini berusaha mempertahankan keberadaan bangunan, lingkungan maupun situs cagar budaya yang ada di Kota Surabaya. Pemerintah Kota Surabaya juga membentuk Tim Cagar Budaya dengan mengeluarkan Surat Keputusan Walikota no. 188.45/36/402.1.04/1996 pada tahun 1998 dengan menetapkan 61 cagar budaya kota Surabaya berhasi dilindungi. Hal ini diperkuat dengan penetapan kembali beberapa temuan cagar budaya baru berdasarkan SK Walikota no. 188.45/207/402.1.04/1998 dan menetapkan lagi, jumlah temuan terbaru yang berhasil didata (Alrianingrum, 2010).

Pengelolaan dan pelestarian bangunan cagar budaya di Surabaya, secara berkelanjutan diatur dalam Peraturan Daerah Kota Surabaya Nomor 5 Tahun 2005. Pelestarian tersebut secara jelas tertuang dalam Pasal 2 dengan isi sebagai berikut,

$$
\begin{array}{lcr}
\text { Pelestarian } & \text { bangunan } & \text { dan/atau } \\
\text { lingkungan } & \text { cagar } & \text { budaya } \\
\text { bertujuan: } & &
\end{array}
$$




\begin{abstract}
mempertahankan keaslian
bangunan dan/atau lingkungan

cagar budaya yang mengandung

nilai sejarah, ilmu pengetahuan

dan kebudayaan;

melindungi dan memelihara

bangunan dan/atau lingkungan

cagar budaya dari kerusakan yang

disebabkan oleh tindakan

manusia maupun proses alam;

memanfaatkan bangunan

dan/atau lingkungan cagar

budaya sebagai kekayaan budaya

untuk dikelola sebaik-baiknya

demi kepentingan pembangunan

dan citra kota serta tujuan wisata.
\end{abstract}

Pengelolaan dan pelestarian bangunan cagar budaya dan situs sebagai peninggalan sejarah tentu mempunyai dampak positif terhadap kelestarian sejarah lokal. Pemahaman dan informasi sejarah lokal didapat dari keberadaan situs-situs lokal, disamping sumber lisan dari para pelaku maupun sumber lisan yang dituturkan secara turun-temurun. Pelestarian dan pengenalan sejarah lokal juga menjadi kewajiban seluruh pihak, tidak terbatas pada pemerintah melalui peraturan perundang-undangan. Peran aktif masyarakat melalui keberadaan komunitas penggiat sejarah merupakan wujud dukungan positif terhadap pengelolaan dan pelestarian bangunan cagar budaya dan pengenalan sejarah lokal pada masyarakat.

\section{PENGENALAN SEJARAH LOKAL BERBASIS RE-ENACMENT OLEH ROODEBRUG SOERABAIA}

Roodebrug Soerabaia merupakan sebuah komunitas penggiat sejarah yang ada di kota Surabaya. Berdasar wawancara dengan Ady Setiawan, salah satu pendiri komunitas penggiat sejarah Roodebrug Soerabaia didapat informasi bahwa pendirian komunitas ini merupakan sebuah respon terhadap keberadaan situs dan sumber sejarah yang ada di Kota Surabaya. Surabaya yang dikenal sebagai kota pahlawan lambat laun, menurut Ady Setiawan, telah mengalami penurunan makna. Pembangunan kota yang semakin pesat, tidak jarang menggeser makna dan identitas Surabaya sebagai Kota Pahlawan menjadi Kota Metropolitan (Wawancara dengan Ady Setiawan, 5 Maret 2017). Identitas sebagai kota Pahlawan menjadi potensi besar dalam rangka pembangunan karakter masyarakat. Sebagai upaya dalam melestarikan sejarah, Roodebrug Soerabaia kemudian bergiat untuk memperkenalkan sejarah lokal Surabaya kepada masyarakat melalui beragam kegiatan, salah satunya adalah reka ulang sejarah.

Berdasar wawancara dengan Satrio Sudarso, didapatkan informasi bahwa reka ulang sejarah secara rutin dilaksanakan pada minggu terakhir di tiap bulan. Menurut Satrio, reka ulang sejarah merupakan kegiatan rutin dan cukup sederhana yang diselenggarakan oleh Roodebrug Soerabaia. Melalui teatrikal diharapkan aka nada pesan dan pengetahuan sejarah yang tersampaikan kepada masyarakat (Wawancara dengan Satrio Sudarso, 25 Nopember 2016). Sejarah lokal Surabaya, terlebih yang berkaitan dengan periode perang kemerdekaan menjadi objek dan tema yang diangkat oleh Roodebrug Soerabaia dalam reka ulang sejarah yang diselenggarakan. Hal ini tentu sangat potensial dalam rangka menumbuhkan nilai-nilai patriotis pada masyarakat.

Naskah yang dipergunakan dalam reka ulang sejarah, didapat melalui riset terhadap sumber-sumber pustaka maupun penggalian informasi lisan yang dilakukan oleh Roodebrug Soerabaia kepada para pelaku sejarah pertempuran Surabaya yang masih dapat ditemui Hari Sasongko (60 tahun), salah seorang anggota Roodebrug Soerabaia menuturkan bahwa ada peran 
anggota dalam penelitian, penyususnan, pelatihan teatrikal hingga pementasan. Hal ini diungkapkan oleh Hari Sasongko sebagai berikut:

Naskah itu dibuat melalui riset

kesejarahan yang dilakukan teman-teman.Tentu melalui bukubuku sejarah yang berkaitan dengan pertempuran Surabaya. Setelah itu, akan dibuat rekamannya. Setelah naskah jadi, baru dibagi ke teman-teman yang akan mengikuti teatrikal. Biasanaya, sebelum pementasan, kami akan melakukan latihan. Nah, dari buku-buku itu juga saya kemudian membayangkan, bahwa yang ikut perang ini juga rakyat. Padahal sebelumnya, kalau ada teatrikal teman-teman lebih suka jadi pejuang yang bawa senjata atau jadi tentara Inggris. Dari buku-buku yang dipelajari bersama, kami kemudian juga membuat pembaruan naskah dan cerita. Sebisa mungkin biar lebih mirip (Wawancara dengan Hari Sasongko, 24 Nopember 2016).

Reka ulang peristiwa sejarah menjadi salah satu aktivitas menarik yang dilakukan oleh RB dalam rangka memperkenalkan sejarah lokal kepada masyarakat. Aktivitas mereka ulang sejarah, juga dikenal dengan istilah $R e$ enacment. Re-enacment menjadi suatu kegiatan belajar sejarah yang pada dasarnya telah cukup dikenal di dunia pendidikan. Namun, masih jarang dijumpai di Indonesia, terlebih dalam rangka mempelajari sejarah lokal. Re-enacment pada dasarnya memiliki kemiripan dengan aktivitas bermain peran dalam pembelajaran sejarah. Akan tetapi terdapat beberapa perbedaan dalam proses penyampaian informasi.
Re-enacment berfokus pada upaya dalam menampilkan kembali kehidupan di masa lampau. Upaya ini dilakukan melalui cara dan pendekatan guna mendapatkan gambaran semirip mungkin dengan kondisi yang pernah terjadi (Hamid, 2014 : 97). Perhatian lebih ditujukan, misalnya pada perkakas apa saja yang digunakan, model pakaian, gerak tubuh, serta kondisi lingkungan yang dibuat semirip mungkin. Pelaku Re-enacment biasa disebut dengan Re-enactor. Re-enacment juga menuntut Re-enactor untuk mampu menjiwai peran yang dimainkan. Hal ini bertujuan agar sebuah peristiwa sejarah, bisa disajikan kembali dengan kondisi semirip mungkin.

Howard Giles (dalam Hamid, 2014:

37) menjelaskan bahwa Re-enacment adalah cara untuk mengunjungi masa lalu. Masa lalu dipahami sebagai waktu yang telah terjadi sebelum hari ini, yang disusun secara rapi dan detail. Kegiatan ini bertujuan untuk menarik minat orang-orang untuk mengunjungi tempat bersejarah, sekolah, dan sebagainya. Secara ringkas dapat disimpulkan bahwa Re-enacment dapat membantu membangun desain sebuah atraksi budaya (pariwisata) dan meningkatkan minat penikmat sejarah terhadap objek sejarah.

Aktivitas mereka ulang sebuah peristiwa untuk kemudian ditampilkan dalam bentuk drama tetarikal juga merupakan salah satu terobosan menarik dalam rangka mempelajari sejarah. Drama maupun reka ulang sejarah pada hekekatnya merefleksikan secara artistik seluruh proses dari kehidupan manusia dan akan terdapat sifat-sifat penting dari realitas objektif didalamnya. Kekayaan sifat yang dimiliki oleh drama, bersumber pada kehiduppan sehari-hari. Pada apa yang nampak, terdapat gambaran yang mewakili suatu kisah dan menjadi perwujudan total dari suatu proses kehidupan (Kartodirdjo, 1987: 174-175). 
Bermain peran, dalam konteks aktivitas pembelajaran sejarah di lembaga pendidikan formal, menurut Wijaya (2016: 56-57) bertujuan untuk memberikan pemahaman lebih bagi peserta didik melalui pembelajaran yang inovatif, dan dilaksanakan melalui beberapa tahap. Adapun tahapan tersebut meliputi tahap persiapan, pelaksanaan, dan tindak lanjut. Aktivitas bermain peran juga mampu memberikan gambaran bagi seseorang terhadap tokoh yang diperankan. Sehingga, secara tidak langsung, ada suatu pengetahuan yang didapat mengenai sifatsifat tokoh yang diperankan (Wijaya, 2016: 69). Tahap persiapan, pelaksanaan, hingga tindak lanjut juga dilakukan oleh RB, meskipun komunitas ini bukan bagian dari lembaga pendidikan formal.

Collingwood (dalam Hamid, 2014:

116-117) menjelaskan bahwa ada enam aspek yang perlu diperhatikan oleh seseorang dalam melakukan reka ulang sebuah peristiwa sejarah untuk kemudian coba ditampilkan kembali. Adapun aspekaspek tersebut ialah :

1. Kerangka pengetahuan dari peristiwa yang akan ditampilkan.

2. Penuturan maupun penyampaian kisah harus kronologis dan memiliki kausalitas.

3. Ada improvisasi dalam menampilkan ungkapan-ungkapan dan perilaku pelaku sejarah.

4. Pengkondisian tempat, dengan tujuan agar fokus penonton bisa tertuju pada pelaku.

5. Respon singkat yang mampu menarik perhatian.

6. Alur kisah ditampilkan secara menarik dengan ilustrasi-ilustrasi ringan dan berkait dengan kehidupan sehai-hari.

Aspek-aspek tersebut menjadi salah satu patokan dalam melaksanakan reka ulang sebuah peristiwa sejarah yang ditampilkan dalam drama teatrikal. Aktivitas ini di beberapa tempat juga dikenal dengan istilah Re-enacment (reka ulang peristiwa) dengan pelaku yang lazim dikenal dengan sebutan Re-enactor (pereka ulang)

Re-enacment yang dilakukan oleh RB menjadi berbeda, ketika hal ini dilakukan diluar aktivitas pendidikan formal. Sasaran utama dalam kegiatan ini juga cukup jelas, yaitu memperkenalkan sejarah lokal kepada masyarakat. Sejarah lokal Surabaya, sebagaimana telah disinggung sebelumnya, telah menjadi bagian dari sejarah nasional. Historiografi lokal berkait dengan Surabaya, bahkan telah menjadi salah satu peristiwa besar yang berdampak pada sejarah nasional. Meskipun sejarah nasional dan sejarah lokal memiliki kategori unit historis sendiri-sendiri, tetapi tidak bisa dipungkiri adanya keterkaitan antara peristiwaperistiwa dalam konteks nasional dan konteks lokal. Dengan kata lain, realitas peristiwa sejarah di kedua level hanya bisa dimengerti lebih baik apabila ditarik dalam prespektif makro dan mikro. Keterkaitan sejarah nasional dengan sejarah lokal tentu saja bukan harus diartikan bahwa sejarah nasional itu sendiri adalah semata-mata gabungan dari sejarah-sejarah di tingkat lokal. Masing-masing lokalitas memiliki realitas kesejarahannya sendiri yang hanya bisa dimengerti dalam rangka lokalitas itu (Widja, 1991: 38). Tantangan ke depan yang musti dihadapi oleh para pemerhati sejarah, baik akademisi maupun komunitas penggiat sejarah ialah bagaimana memperkenalkan sejarah lokal secara kreatif dan inovatis kepada masyarakat.

\section{KESIMPULAN}

Potensi sejarah lokal yang dimiliki oleh Surabaya cukup besar. Berbeda 
dengan beberapa daerah lain pada umumnya, peranan penting Surabaya selama beberapa abad telah menjadikan Surabaya sebagai salah satu objek penelitian sejarah. Hal ini berdampak pada banyaknya karya sejarah lokal Surabaya yang mengupas beragam aspek sejarah dari tiap zaman. Peninggalan sejarah, baik berupa situs maupun bangunan cagar budaya, juga cukup mudah ditemui. Perlindungan terhadap keberadaan situs dan bangunan cagar budaya di Surabaya telah diatur sedemikian rupa melalui peraturan perundang-undangan yang dikeluarkan oleh Pemerintah Kota Surabaya.

Potensi sejarah lokal yang ada di Surabaya turut mengundang respon masyarakat dan salah satunya melalui keberadaan komunitas penggiat sejarah. Roodebrug Soerabaia. Komunitas ini secara konsisten dan inovatif memperkenalkan sejarah lokal Surabaya kepada masyarakat melalui beragam aktivitas, salah satunya adalah Reenacment. Pengenalan sejarah berbasis $R e$ enacment merupakan sebuah inovasi lebih lanjut dari kegiatan bermain peran. Reenactor sebagai pelaku Re-enacment diharapkan mampu memahami sebuah peristiwa sejarah dan peran yang dimainkan. Re-enacment juga menuntut penggunaan perkakas semirip mungkin dalam proses penyampaian informasi sejarah kepada masyarakat. Harapannya adalah, adanya sebuah pemahaman utuh dari masyarakat terhadap sebuah peristiwa sejarah yang disampaikan.

\section{RUJUKAN}

\section{Lisan}

Ady Setiawan

Hari Sasongko

Satrio Sudarso

\section{Koran}

Jawa Pos. Senin 25 April 2016. Kenang Pertempuran Jelang 10 Nopember, hal. 20.

Jawa Pos. Kamis 27 Oktober 2016. Roodebrug Soerabaia, Ajak Anak Muda Kenali Sejarah Kota, Hal 20

\section{Buku}

Abdulgani, R. 1980. Seratus Hari di Surabaya yang Menggemparkan Indonesia. Jakarta. Yayasan Idayu

Alrianingrum, S. 2010. Cagar Budaya Surabaya kota Pahlawan sebagai Sumber Belajar. Tesis tidak diterbitkan pada Program Pascasarjana Universitas Sebelas Maret Surakarta.

Basundoro, P. 2013. Merebut Ruang Kota: Aksi Rakyat Miskin Kota Surabaya 1900 - 1960-an. Tangerang Selatan. Marjin Kiri.

Doulton, 2002. The Fighting Cick: Being The History of The $23^{\text {rd }}$ Indian Division, 1942-1947. Eastbourne. Naval Military Press

Frederick, W.H. 1988. Pandangan dan Gejolak: Masyarakat Kota dan Lahirnya Revolusi Indonesia (Surabaya 19261946). Jakarta. PT. Gramedia

Hamid, A.R. 2014. Pembelajaran Sejarah. Yogyakarta. Ombak

Kartodirdjo, S. 1987. Kebudayaan Pembangunan dalam Prespektif Sejarah. Yogyakarta. Gajah Mada University Press.

Notosusanto, N. 1979. Tentara Peta: pada jaman pendudukan Jepang di Indonesia. Jakarta. Gramedia. 
Ricklefs, M.C. 1989. Sejarah Indonesia Modern. Yogyakarta. Gadjah Mada University Press

Soedjatmoko.1984. Kesadaran Sejarah dan Pembangunan dalam Dimensi Manusia dalam Pembangunan : Pilihan karangan Soedjatmoko. Jakarta. LP3ES

Thorn. M.W. 2011. Penaklukkan Pulau Jawa-Pulau Jawa Abad ke 19 Dari Amatan Seorang Serdadu Kerajaan Inggris. Jakarta. Elex Media Komputindo.

Timoer, S. 1983. Mitos Cuũra-Bhaya : Cerita Rakyat sebagai Sumber Penelitian Sejarah Surabaya. Jakarta. Balai Pustaka

Widja, I.G. 1991. Sejarah Lokal Suatu Prespektif Dalam Pengajaran Sejarah. Bandung. Angkasa

Wijaya, D. 2016. Menjadi Sejarawan Pendidik. Yogyakarta. Deepublish.

Wiryoprawiro, Z.M. 1986. Perkembangan Arsitektur Masjid di Jawa Timur. Surabaya. PT.Bina Ilmu 